\title{
Karakteristik Pektin Kulit Buah Sukun (Artocarpus altilis (Park.) Fosberg) dan Uji Kemampuan Adsorpsi Logam Berat pada Limbah Laboratorium Stifera Semarang
}

\author{
Khoirul Anwar ${ }^{1 *}$, Mardiyono ${ }^{1)}$, Nuraini Harmastuti ${ }^{1)}$ \\ 1) Fakultas Farmasi Universitas Setia Budi, Surakarta, Indonesia \\ ${ }^{*}$ Corresponding author: anwarkhoirul174@gmail.com
}

\begin{abstract}
ABSTRAK
Uji karakteristik pektin kulit buah sukun (Artocarpus altilis (Park.) Fosberg) dan uji kemampuan adsorpsi logam berat pada limbah laboratorium stifera Semarang. Tujuan penelitian ini yaitu menentukan kondisi optimum pektin kulit buah sukun dalam menyerap ion $\mathrm{Pb}^{2+}$ dan $\mathrm{Cd}^{2+}$ terhadap parameter variasi berat, lama waktu kontak, $\mathrm{pH}$ dan ukuran partikel serta menentukan persentase penurunan kadar ion $\mathrm{Pb}^{2+}$ dan $\mathrm{Cd}^{2+}$ pada limbah cair laboratorium farmasi. Metode isolasi pektin dilakukan dengan menggunakan metode konvensional dan dilakukan pengujian karakteristik pektin yaitu uji kadar air, kadar abu, berat ekivalen, kadar metoksil, kadar galakturonat, derajat esterifikasi, identifikasi FTIR dan GC-MS. Uji kemampuan adsorpsi logam berat dengan 4 variasi optimasi yaitu berat pektin yaitu 100, 300 dan 500 mg; lama waktu kontak 30, 60, 90 dan 120 menit; pH 4, 5, 6 dan 7; variasi ukuran partikel 80, 100 dan 120 mesh, metode analisis menggunakan alat spektrofotometri serapan atom. Hasil penelitian menunjukkan bahwa berat optimum terjadi pada $500 \mathrm{mg}$, lama waktu kontak 90 menit, pH 5 dan ukuran partikel 120 mesh baik ion $\mathrm{Pb}^{2+}$ dan $\mathrm{Cd}^{2+}$. Hasil tersebut diaplikasikan pada limbah laboratorium farmasi dan didapatkan rata-rata persentase penurunan ion logam $\mathrm{Pb}^{2+}$ 90,53\% dan ion $\mathrm{Cd}^{2+} 91,51 \%$.
\end{abstract}

Kata kunci: Adsorpsi; kulit buah sukun; pektin

\section{Characteristics of Breadfruit Peel Pectin (Artocarpus altilis (Park.) Fosberg) and Ability Test of Heavy Metal Adsorption in Waste Stifera Laboratory Semarang}

\begin{abstract}
Characteristic test of pectin of breadfruit peel (Artocarpus altilis (Park.) Fosberg) and test of heavy metal adsorption ability in laboratory waste Stifera Semarang. The aim of this study was to determine the optimum conditions for pectin to absorb $\mathrm{Pb}^{2+}$ and $\mathrm{Cd}^{2+}$ ions on the parameters of weight variation, contact time, $\mathrm{pH}$ and particle size and to determine the percentage decrease in $\mathrm{Pb}^{2+}$ and $\mathrm{Cd}^{2+}$ ion levels in pharmaceutical laboratory wastewater. Pectin isolation method was carried out using conventional methods and the characteristics of pectin were tested, namely water content, ash content, equivalent weight, methoxyl content, galacturonic content, esterification degree, FTIR identification, GC-MS. Heavy metal adsorption ability test with optimization variations, namely the weight of pectin is $100,300,500 \mathrm{mg}$; length of contact time $30,60,90,120$ minutes; $\mathrm{pH} 4,5,6,7$; variation of particle size 80, 100, 120, analytical method using atomic absorption spectrophotometry. The results showed that the optimum weight occurred at $500 \mathrm{mg}$, contact time of 90 minutes, $\mathrm{pH} 5$ and particle size of 120 both $\mathrm{Pb}^{2+}$ and $\mathrm{Cd}^{2+}$ ions. These results were applied to pharmaceutical laboratory waste and the average percentage reduction of metal ions $\mathrm{Pb}^{2+}$ was $90.53 \%$ and $\mathrm{Cd}^{2+}$ ions were $91.51 \%$.
\end{abstract}

Keywords: Adsorption; breadfruit peel; pectin

(Article History: Received 04-08-2021; Accepted 29-01-2022; Published 31-01-2022)

\section{PENDAHULUAN}

Pencemaran lingkungan merupakan salah satu faktor rusaknya lingkungan yang akan berdampak pada makhluk hidup di sekitarnya. Salah satu pencemaran tersebut disebabkan oleh limbah yang berasal dari kegiatan laboratorium. Persoalan spesifik limbah yang mengandung logam berat adalah dapat terakumulasi dalam makhluk hidup 
melalui rantai makanan. Zat-zat pencemar lebih didominasi oleh bahan buangan logam berat seperti merkuri, tembaga, kadmium, timbal.

Komponen yang berperan dalam proses adsorpsi logam berat dengan adsorben bahanbahan biologis adalah keberadaan gugus aktif yang ada di bahan tersebut. Gugus-gugus tersebut diantaranya adalah gugus acetamido pada kitin, gugus amino dan posphat pada asam nukleat, gugus amido, amino, sulphydryl, karboksil pada protein dan gugus hidroksil pada polisakarida (Nafikatus et al., 2017). Salah satu senyawa dalam limbah kulit buah sukun yang mengandung gugus-gugus pengikat logam tersebut adalah pektin (Madjaga et al., 2017)

Pektin merupakan salah satu senyawa yang terdapat pada dinding sel tumbuhan. Pektin tersusun atas polimer dari asam Dgalakturonat yang dihubungkan oleh ikatan 1,4 glikosidik (Febriyanti et al., 2018) Selama ini pektin dimanfaatkan dalam industri makanan, farmasi dan kosmetik terutama sebagai bahan pembentuk gel, namun bila mengingat bahwa struktur kompenen pektin juga banyak mengandung gugus aktif pengikat logam seperti hidroksil dan karboksilat, maka pektin juga dapat digunakan sebagai salah satu sumber biosorben (Hastuti, 2016).

Penelitian Madjaga et al. (2017) menyatakan bahwa didalam kulit buah sukun mengandung pektin sehingga sangat potensial untuk dimanfaatkan. Menurut Kurniasari et al. (2012) didapatkan penyerapan ion logam $\mathrm{Pb}^{2+}$ sebesar 97,89\% dan $\mathrm{Cd}^{2+}$ sebesar 93,96\% menggunakan pektin citrus termodifikasi. Modifikasi pektin menyebabkan penurunan derajat esterifikasi sehingga dapat meningkatkan aktivitas penjerapan karena semakin rendah DE pektin maka gugus aktif pektin semakin banyak.

Faktor yang mempengaruhi kapasitas adsorpsi adalah waktu kontak, berat adsorben, pH dan ukuran partikel (Renyaan et al., 2017). Semakin lama waktu kontak adsorpsi maka semakin lama pula frekuensi tumbukan diantara partikel dengan adsorben, adsorpsi pun semakin meningkat hingga mencapai keadaan kesetimbangan. Semakin besar berat pektin sebanding dengan bertambahnya jumlah partikel dan luas permukaan pektin sehingga menyebabkan jumlah tempat mengikat ion logam juga bertambah dan efisiensi penyerapan pun meningkat (Refilda,
2001). Menurut penelitian yang dilakukan oleh Renyaan et al. (2017) diperoleh hasil penyerapan ion logam kadmium $\left(\mathrm{Cd}^{2+}\right)$ mencapai 93,07\% menggunakan pektin kulit buah semangka dengan berat pektin 1,5 gram dan lama waktu penyerapan maksimal 1 jam.

Derajat keasaman $(\mathrm{pH})$ mempengaruhi muatan situs aktif, misalnya gugus karboksil yang terdapat pada permukaan adsorben, pada $\mathrm{pH}$ yang sangat rendah (asam) mengakibatkan permukaan dinding sel adsorben bermuatan positif, sehingga memperkecil kemungkinan untuk mengikat ion logam yang bermuatan positif (Kusmiyati et al., 2012). Penelitian Suryono (2017) diperoleh penyerapan optimum ion $\mathrm{Pb}^{2+}$ adalah pada $\mathrm{pH} 5$ dengan penurunan berturut-turut sebesar $61,02 \%$. Semakin kecil ukuran partikel biosorben, semakin besar pula luas permukaan untuk mengadsorpsi sehingga penyerapannya akan semakin meningkat. Penelitian Imelda (2019) diperoleh hasil penyerapann yang maksimum pada ukuran mesh 100 sebesar 99,57\%.

Berdasarkan penelitian yang dilakukan oleh Renyaan et al. (2017), Suryono (2017) dan Imelda (2019) tersebut maka dilakukan penelitian dengan tujuan untuk menentukan kondisi optimum pektin kulit buah sukun dalam menyerap ion $\mathrm{Pb}^{2+}$ dan $\mathrm{Cd}^{2+}$ terhadap parameter variasi berat, lama waktu kontak, $\mathrm{pH}$ dan ukuran partikel serta menentukan persentase penurunan kadar ion $\mathrm{Pb}^{2+}$ dan $\mathrm{Cd}^{2+}$ pada limbah cair laboratorium farmasi.

\section{METODE PENELITIAN}

Sampel yang digunakan dalam penelitian adalah kulit buah sukun yang diperoleh dari Desa Dukuhseti, Kabupaten Pati, Jawa tengah. Determinasi dilakukan oleh Laboratorium Morfologi \& Sistematika Tumbuhan Laboratorium farmasi "STIFAR" Semarang.

Bahan-bahan yang digunakan dalam penelitian ini adalah kulit buah sukun (Artocarpus altilis (Park.) Fosberg). Sedangkan bahan-bahan kimia yang digunakan untuk proses terdiri dari etanol $96 \%, \mathrm{HCl}, n$-heksan teknis $\mathrm{NaOH}$ (pa), aquadest, $\mathrm{NaCl}, \mathrm{NaOH}, \mathrm{Pb}\left(\mathrm{NO}_{3}\right)_{2}$ dan $\mathrm{CuSO}_{4}$.

\section{Proses Pembuatan Serbuk Kulit Buah Sukun}

Buah sukun yang dipilih adalah yang sudah tua, kemudian dilakukan pengupasan untuk memperoleh kulit buah sukun dan 
dicuci dengan air bersih untuk menghilangkan sisa-sisa kotoran yang masih menempel, selanjutnya dilakukan perendaman dengan menggunakan pelarut $n$-heksan selama 12 jam untuk menghilangkan getah yang menempel pada kulit buah sukun, kemudian kulit buah sukun dikeringkan menggunakan almari pengering selama 3 hari. Kulit buah sukun yang sudah kering digiling dengan menggunakan blender dan diayak menggunakan ayakan 30/40 mesh.

\section{Proses Isolasi Pektin}

Sebanyak $150 \mathrm{~g}$ serbuk kulit buah sukun dengan penambahan air sebanyak 1:3, kemudian ditambahkan pelarut $\mathrm{HCl} 0,1 \mathrm{~N}$ sampai $\mathrm{pH}$ 1,5 sehingga menjadi bubur asam, kemudian diekstraksi menggunakan metode konvensional dengan suhu $80^{\circ} \mathrm{C}$ dan waktu 180 menit. Hasil ekstraksi disaring dengan kain kola dalam keadaan panas. Filtrat yang diperoleh didiamkan hingga dingin pada suhu ruangan $\left(25^{\circ} \mathrm{C}\right)$, kemudian ditambahkan etanol asam (etanol 96\%: $2 \mathrm{~mL} \mathrm{HCl}$ ) kedalam filtrat dengan rasio $1: 1,5$ etanol asam dan diamkan selama 24 jam.Endapan pektin disaring dan dicuci menggunakan etanol 96\% hingga bebas klorida, kemudian dikeringkan pada suhu $40^{\circ} \mathrm{C}$ selama 8 jam menggunakan oven. Pektin kering digerus dan diayak dengan menggunakan ayakan 80, 100 dan 120 mesh hingga menjadi serbuk pektin yang homogeny (Fitriani, 2002).

\section{Analisis Karakteristik Pektin}

1. Analisis Spektrum FTIR Pektin Kulit Buah Sukun

Sampel pektin dan pembanding masing-masing dicampur dengan $\mathrm{KBr}$ kemudian digerus halus. Campuran tersebut kemudian dijadikan pelet dan diukur spektrumnya menggunakan spektrofotometer FTIR pada bilangan gelombang 4000$400 \mathrm{~cm}^{-1}$.

2. Kadar air (Pardede et al., 2013)

Sebanyak 1 gram pektin ditimbang dan diletakkan didalam krus yang telah dikonstankan, kemudian dimasukkan kedalam oven pada suhu $105^{\circ} \mathrm{C}$ selama $1 \mathrm{jam}$. Setelah itu didinginkan dalam desikator selanjutnya ditimbang sampai mendapatkan berat tetap.

$\%$ kadar air $=$

Berat zat awal - berat zat konstan berat zat awal
3. Kadar Abu (Pardede et al., 2013)

Sebanyak 1 gram pektin ditimbang dan dimasukkan kedalam krus yang telah dikonstankan, kemudian ditempatkan dalam muffle pada suhu $600^{\circ} \mathrm{C}$ selama 3 jam. Setelah itu didinginkan dalam desikator selama satu jam dan selanjutnya di timbang sampai berat tetap.

$\%$ kadar abu $=\frac{\text { berat abu }}{\text { berat pektin }} \times 100 \%$

4. Penentuan Berat Ekuivalen Pektin Kulit

Buah Sukun (Febriyanti et.al., 2018)

Penentuan berat ekuivalen pektin dilakukan dengan titrasi asam basa. Ditimbang seksama 0,5 gram sampel pektin ditambahkan $5 \mathrm{~mL}$ etanol 96\% dan dilarutkan dalam $\mathrm{f} 100$ $\mathrm{mL}$ air suling yang berisi 1 gram $\mathrm{NaCl}$. Larutan tersebut dititrasi perlahan-lahan dengan $\mathrm{NaOH} \quad 0,1 \mathrm{~N}$ memakai indikator phenolptalein $1 \%$ sampai terjadi perubahan warna menjadi merah muda ( $\mathrm{pH} 7,5)$ yang bertahan minimum 30 detik.

Berat Ekivalen $=\frac{\text { bobot pektin }(\mathrm{mg})}{\mathrm{V} \mathrm{NaOH} \times \mathrm{N} \mathrm{NaOH}}$

5. Penentuan Kadar Metoksil Pektin Kulit

Buah Sukun (Febriyanti et.al., 2018)

Larutan netral dari penentuan berat

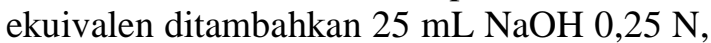
dikocok dan dibiarkan selama 30 menit pada suhu kamar dalam keadaan tertutup. Selanjutnya ditambahkan $25 \mathrm{~mL} \mathrm{HCl} \mathrm{0,25} \mathrm{N}$ dan dititrasi dengan $\mathrm{NaOH} 0,1 \mathrm{~N}$ dengan indikator phenolptalein $1 \%$ sampai titik akhir seperti pada penentuan berat ekuivalen pektin. $\%$ Kadar Metoksil $=$

$$
\frac{\mathrm{V} \mathrm{NaOH} \times 31 \times \mathrm{N} \mathrm{NaOH}}{\text { bobot pektin }(\mathrm{mg})} \times 100 \%
$$

Keterangan:

31 : Bobot molekul metoksil yang berupa $\mathrm{CH}_{3} \mathrm{O}$.

6. Penentuan Kadar Galakturonat Pektin

Kulit Buah Sukun (Febriyanti et.al., 2018)

Kadar galakturonat dihitung dari $\mathrm{mEq}$ (miliekivalen) $\mathrm{NaOH}$ yang diperoleh dari penentuan BE dan kandungan metoksil.

$\%$ Kadar Asam Galakturonat $=$ $\frac{m E q \text { berat ekicalen }+m E q \text { metoksil } \times 176}{\text { Bobot pektin }(\mathrm{mg})} \times 100 \%$

Keterangan:

176: Berat ekivalen terendah asam pektat

7. Penentuan Derajat Esterifikasi Pektin kulit Buah Sukun (Febriyanti et.al., 2018) 
Pengukuran derajat esterifikasi dihitung dari kadar metoksil dan kadar asam galakturonat yang telah diperoleh.

$\%$ Derajat Esterifikasi $=\frac{\% \text { metoksil } \times 176}{\% \text { galakturonat } \times 31} \times 100 \%$ Keterangan:

31: Bobot molekul metoksil yang berupa $\mathrm{CH}_{3} \mathrm{O}$. 176: Berat ekivalen terendah asam pektat.

8. Uji Kandungan Pektin Kulit Buah Sukun dengan Metode GC-MS

Serbuk pektin kulit buah sukun dilakukan pengujian kandungan dengan menggunakan Gas Chromatography-Mass Spectroscopy (GC-MS). Proses derivatisasi pada penelitian ini menggunakan BSTFA dengan pemanasan. Masing-masing $10 \mathrm{mg}$ pektin dimasukkan kedalam vial, dilarutkan dengan metanol p.a.sampai $5 \mathrm{~mL}$, sampel diambil $100 \mu$ Ldan dikeringkan, kemudian ditambahkan $100 \mu \mathrm{L}$ BSTFA. Vial di Vortex dan dipanaskan pada suhu $60^{\circ} \mathrm{C}-70^{\circ} \mathrm{C}$ selama 10 menit. Setelah dingin sampel diinjekan 100 $\mu \mathrm{L}$.

\section{Penentuan Kondisi Maksimum Penyera- pan Logam $\mathrm{Pb}^{2+}$ dan $\mathrm{Cd}^{2+}$}

1. Pengaruh $\mathrm{pH}$ Terhadap Penyerapan Ion Logam $\mathrm{Pb}^{2+}$ dan $\mathrm{Cd}^{2+}$

Sebanyak $500 \mathrm{mg}$ pektin kulit buah sukun dimasukkan ke dalam Erlenmeyer, ditambahkan 25,0 mL larutan $\mathrm{Pb}\left(\mathrm{NO}_{3}\right)_{2}$ dan $\mathrm{CdSO}_{4} 25,0$ ppm dengan variasi $\mathrm{pH} 4,5$ dan 6 . Pengaturan $\mathrm{pH}$ dilakukan dengan menggunakan alat $\mathrm{pH}$ meter dan untuk mengatur $\mathrm{pH}$ yang dikehendaki digunakan reagen pengatur $\mathrm{pH}$, dimana untuk mengatur menjadi $\mathrm{pH}$ asam digunakan $\mathrm{HNO} 3$ dan $\mathrm{NaOH}$ untuk basa. kemudian dilakukan pengadukan menggunakan shaker dengan waktu 90 menit. Setelah itu larutan disaring menggunakan kertas whatman no.42 dan filtrat yang dihasilkan ditampung ke botol kaca, selanjutnya diukur dengan Spektrofotometer Serapan Atom (Rahmawati, 2011).

2. Pengaruh Berat Pektin Terhadap Penyerapan Ion Logam $\mathrm{Pb}^{2+}$ dan $\mathrm{Cd}^{2+}$

Pektin kulit buah sukun dengan variasi berat $100 \mathrm{mg}, 300 \mathrm{mg}$ dan $500 \mathrm{mg}$, masingmasing dimasukkan ke dalam Erlenmeyer, ditambahkan masing-masing 25,0 $\mathrm{mL}$ $\mathrm{Pb}\left(\mathrm{NO}_{3}\right)_{2} 25,0 \mathrm{ppm}$ pada kondisi $\mathrm{pH}$ 5. Hal sama juga dilakukan pada larutan $\mathrm{CdSO}_{4}$ dengan variasi berat $100 \mathrm{mg}, 300 \mathrm{mg}$ dan 500 $\mathrm{mg}$, masing-masing dimasukkan ke dalam
Erlenmeyer, ditambahkan masing-masing 25,0 $\mathrm{mL} \mathrm{CdSO}_{4} 25,0$ ppm pada kondisi pH 5 kemudian diaduk menggunakan shaker selama 60 menit (Ashraf et.al., 2010). Setelah itu larutan disaring menggunakan kertas whatman no.42 dan filtrat yang dihasilkan ditampung ke botol kaca, selanjutnya diukur dengan Spektrofotometer Serapan Atom.

3. Pengaruh Lama Waktu kontak Terhadap Penyerapan Ion Logam $\mathrm{Pb}^{2+}$ dan $\mathrm{Cd}^{2+}$

Sebanyak $500 \mathrm{mg}$ pektin kulit buah sukun dimasukkan ke dalam Erlenmeyer, ditambahkan 25,0 mL larutan $\mathrm{Pb}\left(\mathrm{NO}_{3}\right)_{2}$ dan $\mathrm{CdSO}_{4}$ 25,0 ppm kondisi pH 5 kemudian dilakukan pengadukan menggunakan shaker selama 30, 60, 90 dan 120 menit. Setelah itu larutan disaring menggunakan kertas whatman no.42 dan filtrat yang dihasilkan ditampung ke botol kaca, selanjutnya diukur dengan Spektrofotometer Serapan Atom (Nugraheni \& Herlyanti, 2016).

4. Pengaruh Ukuran Partikel Terhadap Penyerapan Ion Logam $\mathrm{Pb}^{2+}$ dan $\mathrm{Cd}^{2+}$

Sebanyak $500 \mathrm{mg}$ pektin kulit buah sukun dengan variasi ukuran partikel (mesh 40, 80 dan 100) dimasukkan ke dalam Erlenmeyer, ditambahkan $25,0 \mathrm{~mL}$ larutan $\mathrm{Pb}\left(\mathrm{NO}_{3}\right)_{2}$ dan $\mathrm{CdSO}_{4} 25,0$ ppm dengan kondisi pH 5 kemudian dilakukan pengadukan menggunakan shaker dengan waktu 90 menit. Setelah itu larutan disaring menggunakan kertas whatman no.42 dan filtrat yang dihasilkan ditampung ke botol kaca, selanjutnya diukur dengan Spektrofotometer Serapan Atom (Imelda, 2019).

\section{Aplikasi Penggunaan Pektin Kulit Buah Sukun Pada Limbah Cair Laboratorium Farmasi}

Limbah cair laboratorium farmasi disaring untuk memisahkan larutan dari padatan yang tidak larut, kemudian diukur konsentrasi awal ion logam berat $\mathrm{Pb}^{2+}$ dan $\mathrm{Cd}^{2+} \quad$ (sebelum dilakukan adsorpsi menggunakan pektin kulit buah sukun). Selanjutnya limbah diatur dengan menggunakan kondisi maksimum. Dimasukkan pektin kulit buah sukun ke dalam Erlenmeyer, ditambahkan 25,0 mL air limbah yang telah diatur $\mathrm{pH}$ maksimumnya, diaduk menggunakan shaker selama waktu maksimum. Campuran disaring dengan menggunakan kertas saring whatman no. 42 . Filtrat ditempatkan pada vial, kemudian 
diukur dengan Spektrofotometer Serapan Atom.

\section{HASIL DAN PEMBAHASAN}

Berdasarkan hasil penelitian rerata rendemen pektin dari tiga replikasi yang dihasilkan adalah sebesar 46,29\%. Hasil penetapan kadar air pektin kulit buah sukun sebesar 2,80\%. Hasil kadar air tersebut menunjukkan bahwa serbuk pektin kulit buah sukun memenuhi standar Food Chemical Codex yaitu sebesar $\leq 12 \%$. Kadar air pada bahan berpengaruh terhadap masa simpan bahan. Tingginya kadar air dalam pektin dapat menyebabkan kerentanan terhadap aktivitas mikroba (Febriyanti et.al., 2018). Hasil penetapan kadar abu pektin kulit buah sukun sebesar $1,41 \%$. Hasil kadar abu tersebut menunjukkan serbuk pektin kulit buah sukun sudah memenuhi standar Food Chemical Codex. Batas maksimum nilai kadar abu yang diizinkan yaitu $10 \%$. Semakin tinggi tingkat kemurnian pektin maka kadar abu akan semakin rendah, begitupun sebaliknya. (Surhaini, 2016).

Berat ekivalen merupakan ukuran terhadap kandungan gugus asam galakturonat bebas yang terdapat dalam rantai molekul pektin. Asam pektat murni merupakan asam pektat yang seluruhnya tersusun dari asam poligalakturonat yang bebas dari gugus metil ester. Asam pektat murni memiliki berat ekivalen 176. Semakin sedikit gugus asam bebas maka semakin tinggi berat ekivalen sehingga semakin tinggi mutu pektin yang dihasilkan (Tuhuloula et al., 2013). Berdasarkan hasil analisis berat ekivalen pada pektin kulit buah sukun, didapatkan berat ekivalen sebesar 3123,34 g/mol.val. Hal yang dapat mempengaruhi berat ekivalen pektin tergantung pada jenis tanaman, kualitas bahan baku, metode ekstraksi dan perlakuan pada proses ekstraksi (Fitria, 2013).

Pada penelitian ini diperoleh rerata kadar metoksil pektin sebesar 3,04\%. Hal ini menunjukkan bahwa pektin yang diperoleh pada penelitian ini termasuk dalam pektin bermetoksil rendah. Rendahnya kadar metoksil diduga disebabkan oleh adanya peningkatan senyawa non pektat pada dinding sel yang ikut terlarut selama proses ekstraksi. Kadar metoksil rendah yang diperoleh pada penelitian ini lebih menguntungkan karena pektin yang dapat digunakan sebagai adsorben adalah pektin yang memiliki kadar metoksil rendah sehingga dapat langsung diproduksi tanpa melalui proses demetilasi (Maulidiyah et.al., 2014).

Pektin tersusun atas molekul asam galakturonat yang berikatan dengan ikatan $\alpha$ (1-4)-glikosida sehingga membentuk asam poligalakturonat. Semakin tinggi kadar asam galakturonat maka semakin tinggi tingkat kemurnian pektin. Kadar asam galakturonat pektin kulit buah sukun yang diperoleh pada penelitian ini sebesar $91,55 \%$ dan menurut penelitian mandjaga 2017 didapatkan hasil kadar galakturonat pectin kulit buah sukun sebesar $89,76 \%$. Hasil ini lebih tinggi dari pada persyaratan Food Chemical Codex yaitu minimum $65 \%$, sehingga memenuhi persyaratan standar mutu pektin menurut persyaratan Food Chemical Codex.

Derajat Esterifikasi (DE) merupakan perbandingan antara jumlah gugus karbonil yang teresterifikasi dan jumlah gugus karbonil total pada rantai pektin. Pektin yang dihasilkan pada penelitian ini tergolong dalam pektin bermetoksil rendah sehingga dihasilkan persentase derajat esterifikasi dibawah 50\%. Hasil uji derajat esterifikasi pektin kulit buah sukun 18,83\% Hal ini menunjukkan bahwa pektin kulit buah sukun hasil isolasi memiliki kandungan asam galakturonat bebas yang rendah dan jumlah gugus ester yang lebih banyak.

Analisis kualitatif pektin dilakukan dengan menggunakan spektrofotometer infra merah (FTIR) dapat dilihat pada gambar 1 dan baku pektin pada gambar 2, dengan rentang panjang gelombang yang digunakan 4000-400 $\mathrm{cm}^{-1}$. Gugus fungsional utama pektin biasanya terletak pada area bilangan gelombang 1000$2000 \mathrm{~cm}^{-1}$ menunjukkan senyawa keidentikan pektin (Ismail et al., 2012).

Pada bilangan gelombang $3396,42 \mathrm{~cm}^{-1}$ pektin kulit buah sukun dan $3432,78 \mathrm{~cm}^{-1}$ baku pektin menunjukkan intensitas puncak serapan yang kuat dan lebar, hal ini mengindikasikan adanya serapan gugus hidroksil $(\mathrm{O}-\mathrm{H})$ regangan. Hasil yang diperoleh diperkuat dengan pernyataan Hongping et al. (2004), yang menyatakan spektrum ulur $-\mathrm{OH}$ berada pada bilangan gelombang $3100-3700 \mathrm{~cm}$. Pita serapan $1633,17 \mathrm{~cm}^{-1}$ kulit buah sukun dan $1638.22 \mathrm{~cm}^{-1}$ baku pektin menunjukan adanya serapan dari gugus karbonil teresterifikasi $(\mathrm{C}=\mathrm{O})$. Hasil gugus fungsional yang terukur dari spektrum FTIR dengan masing-masing 
serapan pada daerah panjang gelombang tertentu menunjukan kesesuaian dengan struktur pektin. Hal tersebut ditandai dengan terdapatnya vibrasi $(\mathrm{OH})$, ikatan $(-\mathrm{C}-\mathrm{O})$ dan gugus karbonil $(-\mathrm{C}=\mathrm{O})$, sehingga dapat disimpulkan bahwa pektin kulit buah sukun mengandung gugus fungsional pektin.

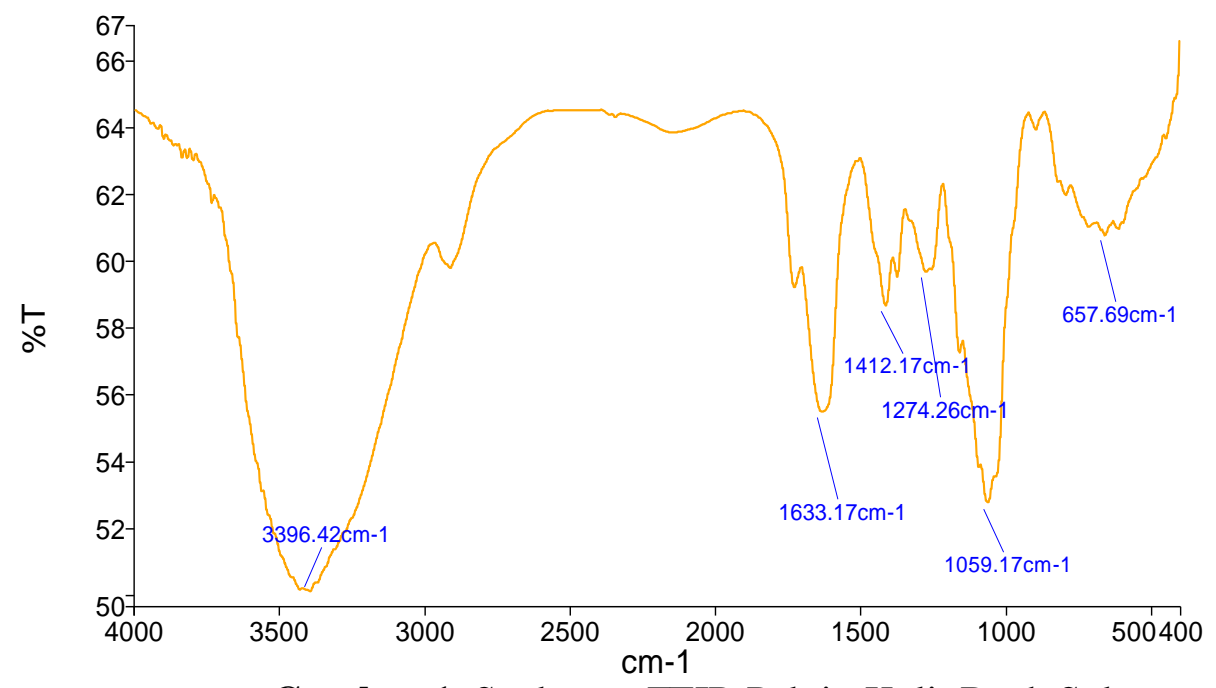

Gambar 1. Spektrum FTIR Pektin Kulit Buah Sukun

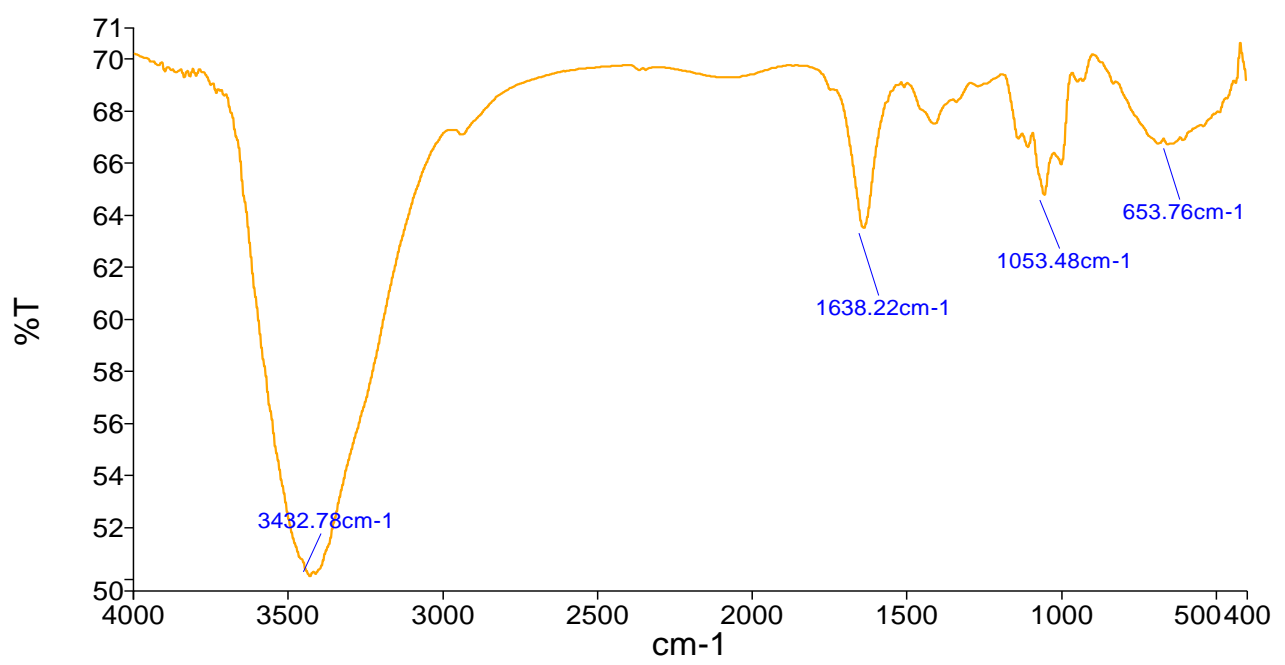

Gambar 2. Spektrum FTIR Baku Pektin

Analisis pektin dilakukan dengan menggunakan GC-MS yang digunakan untuk menentukan kandungan dari pektin dan informasi strukturnya ingin kita ketahui. Analisis GC-MS dari pektin kulit buah sukun menghasilkan bahwa unsur kimia utama adalah senyawa organik, terdapat 20 senyawa kimia yang telah diidentifikasi dari pektin kulit buah sukun dengan analisis GC-MS. Senyawa yang terkandung didalam pektin kulit buah sukun yang paling dominan adalah Hexadecanoic acid kelompok Palmitat dan 2hydroxy-1 Hexadecanoic acid. Asam palmitat dalam tanaman ini merupakan sumber vitamin
A. Hexadecanoic Acid- Methyl Ester dengan $\%$ Area 28.98, Dodecanoic Acid- Methyl Ester dengan \% Area11.62, dimana asam pektinat yang disebut juga dengan pektin, dalam molekulnya terdapat ester metal pada beberapa ester metal pada beberapa gugus karbosil sepanjang rantai polimer dari galakturonat.

Gugus fungsi yang berperan dalam proses adsorpsi $\mathrm{Pb}^{2+}$ dan $\mathrm{Cd}^{2}$ pada pektin adalah gugus karboksilat pada galakturonat. Semakin banyak gugus karboksilat bebas pada rantai pektin, semakin baik kemampuannya untuk menjerap $\mathrm{Pb}^{2+}$ dan $\mathrm{Cd}^{2+}$. Berdasarkan 
hasil analisis pengaruh berat adsorben dengan variasi konsentrasi $100 \mathrm{mg}, 300 \mathrm{mg}$ dan 500 $\mathrm{mg}$, maka dapat diketahui bahwa kondisi optimum penurunan ion $\mathrm{Pb}^{2+}$ menggunakan pektin kulit buah sukun terjadi pada berat adsorben $500 \mathrm{mg}$, dengan nilai efisiensi penurunan sebesar $86,29 \%$, sedangkn untuk ion $\log \mathrm{Cd}^{2+}$ terjadi pada berat adsorben 500 $\mathrm{mg}$ pula, dengan nilai efisiensi penurunan sebesar $86,74 \%$.

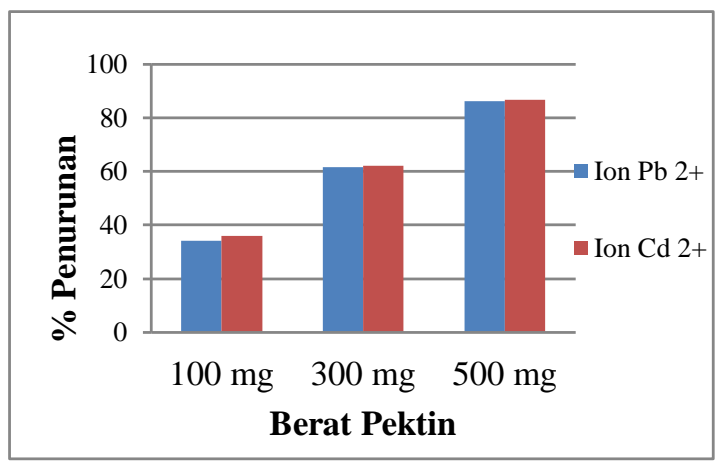

Gambar 3. Penurunan Kadar Ion $\mathrm{Pb}^{2+}$ dan $\mathrm{Cd}^{2+}$ Variasi Berat Menggunakan Pektin Kulit Buah Sukun

Berdasarkan gambar 3 adsorpsi ion $\mathrm{Pb}^{2+}$ dan $\mathrm{Cd}^{2+}$ meningkat dengan bertambahnya berat adsorben. Hal ini disebabkan karena semakin besar berat adsorben yang digunakan, maka efisiensi penyerapannya terhadap ion logam semakin besar. Bertambahnya berat adsorben sebanding dengan bertambahnya jumlah partikel dan luas permukaan adsorben, sehingga menyebabkan jumlah tempat mengikat ion logam juga bertambah dan efisiensi penyerapanpun meningkat (Refilda, 2001).

Berdasarkan hasil analisis pengaruh lama pengadukan dengan variasi waktu 30,60, 90 dan 120 menit, dapat diketahui bahwa kondisi optimum penurunan ion $\mathrm{Pb}^{2+}$ menggunakan pektin kulit buah sukun terjadi pada lama pengadukan 90 menit, dengan nilai efisiensi penurunan sebesar 89,42\%, sedangkan untuk ion logm $\mathrm{Cd}^{2+}$ terjadi pada lama pengadukan 90 menit pula, dengan nilai efisiensi penurunan sebesar $90,25 \%$.

Berdasarkan gambar 4 adsorpsi ion $\mathrm{Pb}^{2+}$ dan $\mathrm{Cd}^{2+}$ meningkat dengan bertambahnya waktu pengadukan, hal ini menunjukkan bahwa persentase desorpsi mengalami peningkatan seiring dengan lamanya waktu kontak yang terjadi, peningkatan ini terjadi sebelum kesetimbangan tercapai. Hal ini disebabkan karena semakin lama interaksi adsorben dengan adsorbat memungkinkan semakin banyaknya tumbukan yang terjadi antara ion logam dengan pektin. Namun pada waktu pengadukan 120 menit, konsentrasi ion $\mathrm{Pb}^{2+}$ dan $\mathrm{Cd}^{2+}$ yang teradsorpsi mulai menurun. Penurunan adsorpsi disebabkan karena situs aktif permukaan pektin telah berada dalam kondisi jenuh oleh ion logam (Riapranita, 2006).

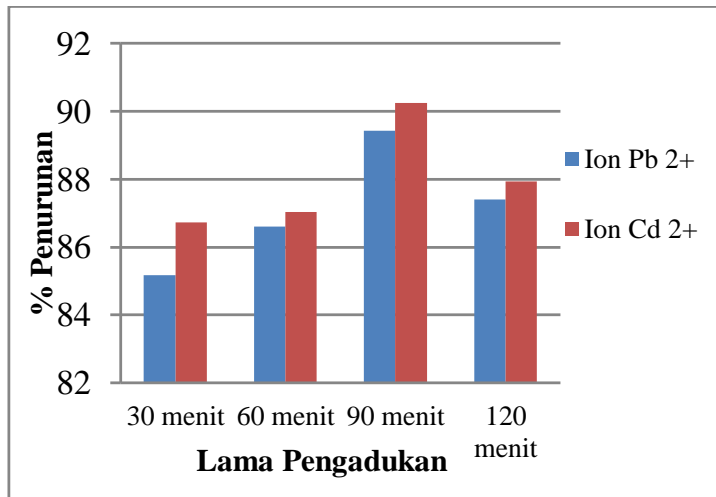

Gambar 4. Penurunan Kadar Ion $\mathrm{Pb}^{2+}$ dan $\mathrm{Cd}^{2+}$ Variasi Lama Pengadukan Menggunakan Pektin Kulit Buah Sukun

Penentuan pengaruh $\mathrm{pH}$ pada proses adsorpsi bertujuan untuk mengetahui $\mathrm{pH}$ optimum yang dapat mengadsorpsi adsorbat. Berdasarkan hasil analisis pengaruh variasi pH 2, 5, 6 dan 7 dapat diketahui bahwa kondisi optimum penurunan ion $\mathrm{Pb}^{2+}$ menggunakan pektin kulit buah sukun terjadi pada $\mathrm{pH} 5$, dengan nilai efisiensi penurunan sebesar $89,06 \%$, sedangkan untuk ion $\operatorname{logm} \mathrm{Cd}^{2+}$ terjadi pada $\mathrm{pH} 5$ dengan nilai efisiensi penurunan sebesar $90,82 \%$.

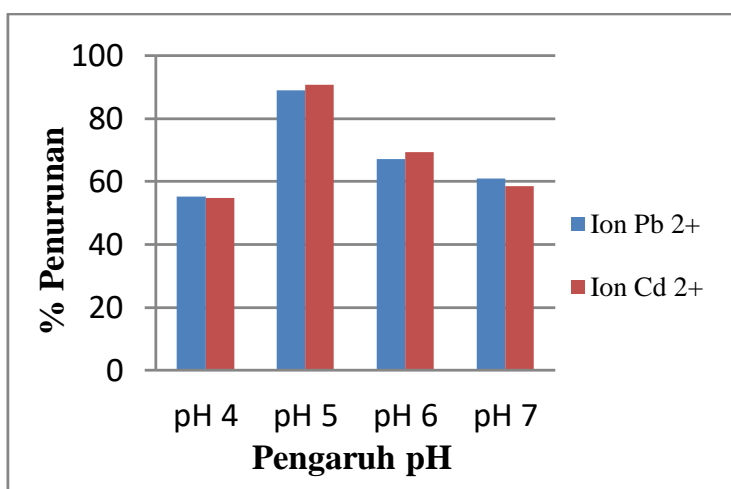

Gambar 5. Penurunan Kadar Ion $\mathrm{Pb}^{2+}$ dan $\mathrm{Cd}^{2+}$ Variasi Lama Pengadukan Menggunakan Pektin Kulit Buah Sukun

Berdasarkan gambar 5 adsorpsi ion $\mathrm{Pb}^{2+}$ dan $\mathrm{Cd}^{2+}$ mengalami peningkatan seiring dengan meningkatnya $\mathrm{pH}$, tetapi mengalami penurunan setelah melewati titik optimum yaang dicapai. Hal tersebut disebabkan karena 
terjadinya pertukaran ion antara adsorben dengan adsorbat. Derajat keasaman $(\mathrm{pH})$ mempengaruhi muatan situs aktif, misalnya gugus karboksil yang terdapat pada permukaan adsorben, pada $\mathrm{pH}$ yang sangat rendah (asam) mengakibatkan permukaan dinding sel adsorben bermuatan positif, sehingga memperkecil kemungkinan untuk mengikat ion logam yang bermuatan positif (Kusmiyati et.al., 2012). Penelitian Suryono (2017) diperoleh penyerapan optimum ion $\mathrm{Pb}^{2+}$ adalah pada $\mathrm{pH} 5$ dengan penurunan berturut-turut sebesar $61,02 \%$. Semakin kecil ukuran partikel biosorben, semakin besar pula luas permukaan untuk mengadsorpsi sehingga penyerapannya akan semakin meningkat. Penelitian Imelda (2019) diperoleh hasil penyerapann yang maksimum pada ukuran mesh 100 sebesar 99,57\%.

Berdasarkan hasil analisis pengaruh ukuran partikel 80, 100 dan 120 mesh dapat diketahui bahwa kondisi optimum penurunan ion $\mathrm{Pb}^{2+}$ menggunakan pektin kulit buah sukun terjadi pada 120 mesh, dengan nilai efisiensi penurunan sebesar $89,22 \%$, sedangkan untuk ion $\operatorname{logm} \mathrm{Cd}^{2+}$ terjadi pada 120 mesh pula, dengan nilai efisiensi penurunan sebesar $90,39 \%$.

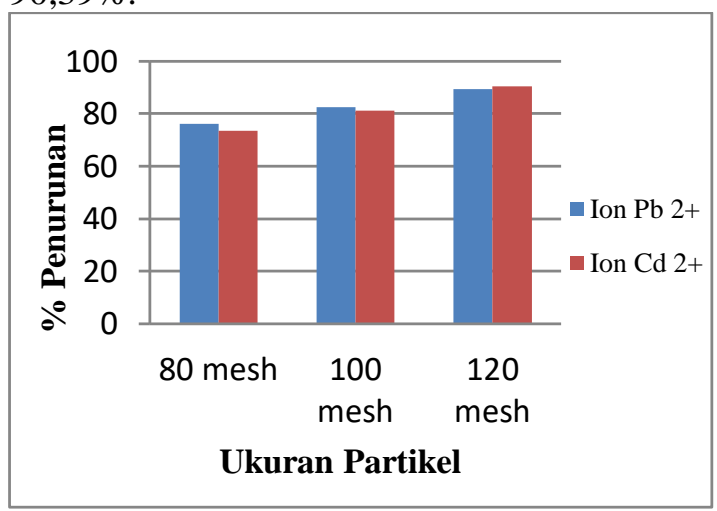

Gambar 6. Penurunan Kadar Ion $\mathrm{Pb}^{2+}$ dan $\mathrm{Cd}^{2+}$ Variasi Lama Pengadukan Menggunakan Pektin Kulit Buah Sukun

Berdasarkan gambar 6 adsorpsi ion $\mathrm{Pb}^{2+}$ dan $\mathrm{Cd}^{2+}$ mengalami peningkatan seiring dengan meningkatnya ukuran mesh, dikarenakan semakin besar ukuran mesh maka semakin kecil ukuran partikel. Semakin kecil ukuran partikel biosorben, semakin besar pula luas permukaan untuk mengadsorpsi sehingga penyerapannya akan semakin meningkat.

Hasil persen efisiensi penurunan ion logam $\mathrm{Pb}^{2+}$ dan $\mathrm{Cd}^{2+}$ menggunakan pektin kulit buah sukun yang diaplikasikan pada limbah laboratorium farmasi didapatkan rata- rata persentase penurunan logam $\mathrm{Pb}^{2+}$ sebesar 90,54\% dan logam $\mathrm{Cd}^{2+}$ sebesar 91,51\%. Pektin adalah adsorben bermuatan negatif karena kaya akan gugus karboksil yang dapat menarik kation logam. Gugus karboksil merupakan salah satu gugus fungsi utama yang mampu menyerap logam secara efektif. Gugus karboksilat dari pektin dapat bereaksi dengan ion logam berat untuk membentuk senyawa kompleks yang tidak larut dalam air.

\section{KESIMPULAN}

Ada perbedaan kemampuan variasi berat, lama waktu kontak, $\mathrm{pH}$ dan ukuran partikel untuk menurunkan ion logam $\mathrm{Pb}^{2+}$ dan $\mathrm{Cd}^{2+}$. Terdapat kondisi maksimum pada berat pektin $500 \mathrm{mg}$, lama waktu kontak 90 menit, pH 5 dan ukuran partikel 120 mesh yang dapat menurukan kadar ion logam $\mathrm{Pb}^{2+}$ dan $\mathrm{Cd}^{2+}$ menggunakan pektin kulit buah sukun (Artocarpus altilis (Park.) Fosberg). Pektin kulit buah sukun (Artocarpus altilis (Park.) Fosberg) dapat menurunkan ion logam $\mathrm{Pb}^{2+}$ dan $\mathrm{Cd}^{2+}$ pada limbah laboratorium farmasi dengan rata-rata persentase penurunan logam $\mathrm{Pb}^{2+}$ sebesar 90,54\% dan $\mathrm{Cd}^{2+}$ sebesar $91,51 \%$.

\section{DAFTAR PUSTAKA}

Ashraf, M.A., Maah, M.J. \& Yusoff, I. 2010. Study of Banana Pell (Musa sapientum) as a Cationic Biosorben. AmericanEurasian Journal of Agriculture \& Environmental Sciience, 8(1): 7-17.

Febriyanti, Y., Razak, A.R. \& Sumarni, N.K. 2018. Ekstraksi dan Karakterisasi Pektin Dari Kulit Buah Kluwih (Artocarpus camansi Blanco). Kovalen, 4(1): 60-73

Fitria, V. 2013. Karakterisasi pektin hasil ekstraksi dari limbah kulit pisang kepok (Musa balbisiana ABB) [Skripsi]. Program Studi Farmasi Fakultas Kedokteran dan Ilmu Kesehatan Universitas Islam Negeri Syarif Hidayatullah, Jakarta.

Fitriani. 2002. Ekstraksi dan Karakterisasi Pektin dari Kulit Jeruk Lemon (Citrus medica var Lemon) [Skripsi]. Fakultas Teknologi Pertanian Institut Pertanian Bogor, Bogor. 
Hastuti， B. 2016. Pektin dan Modifikasinya untuk meningkatkan karakteristik sebagai adsorben. Prosiding Seminar Nasional Kimia dan Pendidikan Kimia VIII: 157-169. ISBN: 978-602-731591-4.

Hongping, H., Ray, F.L. \& Jianxi, Z. 2004. Infrared study of HDTMA. Intercalated Montmorillaonite. Elsevier.

Imelda, D., Khanza, A. \& Wulandari, D. 2019. Pengaruh Ukuran Partikel Dan Suhu Terhadap Penyerapan Logam Tembaga $(\mathrm{Cu})$ Dengan Arang Aktif Dari Kulit Pisang Kepok (Musa paradisiaca formatypica). Jurnal Teknologi, 6(2): 107-118. DOI: 10.31479/jtek.v6i2.10.

Ismail, N.S., Ramli, N., Hani, N.M. \& Meon, Z. 2012. Extraction and Characterization of Pectin from Dragon Fruit (Hylocereus polyrhizus) using Various Extraction Conditions. Sains Malaysiana, 41(1): 41-45.

Kurniasari, L., Hartati, I. \& Satik, N. 2014. Aplikasi Low Methoxyl Pectin (LMP) kulit Pisang Sebagai Biosorben Logam kadmium. Jurnal Prosiding Seminar Nasional Aplikasi Sains \& Teknologi (SNAST), Yokyakarta 15 November 2014, pp. 239-244.

Kusmiyati, Lystanto, P.A. \& Pratiwi, K. 2012. Pemanfaatan Karbon Aktif Arang Batubara (KAAB) Untuk Menurunkan Kadar Ion Logam Berat $\mathrm{Cu} 2+$ dan $\mathrm{Ag}+$ pada Limbah Cair Industri. Reaktor, 14(1): 51-60.

Madjaga, B.H., Nurhaeni, N. \& Rusaln, R. 2017. Ekstraksi pektin dari Kulit Buah Sukun (Artocarpus altilis). Kovalen Jurnal Riset Kimia, 3(2): 158-165.

Maulidiyah, Halimatussadiyah, Susanti, F., Nurdin, M. \& Ansharullah. 2014. Isolasi Pektin dari Kulit Buah Kakao (Theobroma cacao L.) dan Uji Daya Serapnya Terhadap Logam Tembaga $(\mathrm{Cu})$ dan Logam Seng (Zn). Jurnal Agroteknos, 4(2): 113-119.

Nafikatus, S., Napitupulu, M. \& Gonggo, S.T. 2017. Bioadsorpsi Pb(II) Menggunakan Kulit Jeruk Siam (Citrus reticulata). Jurnal Akademika Kimia, 6(3): 160-164.
Nugraheni, B. \& Herlyanti, K. 2016. Penurunan Ion Logam $\mathrm{Pb}$ Menggunakan Dami Nangka Sebagai Adsorben Pada Air Limbah Batik. Jurnal Inovasi Teknik Kimia, 1(2): 6164.

Pardede, A., Ratnawati, D. \& Martono, A. 2013. Ekstraksi dan karakterisasi pektin dari kulit kemiri (Alleuritesmollucana willd). Media Sains, 5(1): 1-6.

Rahmawati, A. 2011. Pengaruh Derajat Keasaman Terhadap Adsorpsi Logam Kadmium (II) dan Timbal (II) Pada Asam Humat. Jurnal Penelitian Sains \& Teknologi, Jurnal Penelitian Sains \& Teknologi, 12(1): 1-14.

Refilda, Rahmiana \& Zein, R. 2001. Pemanfaatan Ampas Tebu Sebagai Bahan Alternatif Pengganti Penyerap Sintetik Logam-logam Berat pada Air Limbah [Skripsi]. Universitas Andalas, Padang.

Riapanitra, A., Setyaningtyas, T. \& Riyani, K. 2006. Penentuan Waktu kontak dan $\mathrm{pH}$ Maksimum Penyerapan Metilen Biru Menggunakan Abu Sekam Padi. Molekul, 1(1): 41-44.

Renyaan, M.S. 2017. Efektivitas Pengikatan Logam Kadmium (Cd) Menggunakan Pektin Kulit Semangka (Citrullus vulgaris) [Skripsi]. Universitas Atmajaya Yogyakarta, Yogyakarta.

Surhaini, S., Indriyani, I. \& Mursalin, M. 2016. Kajian Mutu Pektin dari Kulit Durian Selat dan Aplikasi pada Pengolahan Jeli Nenas Tangkit. Prosiding Seminar Nasional FKPT-TPI Tahun 2016, 1(1): 133-141.

Suryono, B. 2017. Penurunan Ion $\mathrm{Pb}^{2+} \mathrm{Pada}$ Limbah Industri Farmasi "X" di Semarang Menggunakan Arang Ampas Tebu Teraktivasi $\mathrm{H}_{2} \mathrm{SO}_{4}$ dan Teraktivasi $\mathrm{ZnCl}_{2}$ [Skripsi]. Sekolah Tinggi Ilmu Farmasi "Yayasan Pharmasi Seamarang", Semarang.

Tuhuloula, A., Budiyarti, L. \& Fitriana, E.N. 2013. Karakterisasi pektin dengan memanfaatkan limbah kulit pisang menggunakan metode ekstraksi. Konversi, 2(1): 21-27. 